\title{
sciendo
}

Research Article

(C) 2019 Rajamanickam et.al.. This is an open access article licensed under the Creative Commons Attribution-NonCommercial-NoDerivs License (http://creativecommons.org/licenses/by-nc-nd/3.0/).

\section{Introduction of Criminal Law as a Subject in National Secondary Schools}

\author{
Ramalinggam Rajamanickam ${ }^{1^{*}}$ \\ Mohd Safri Mohammed Na'aim² \\ Tengku Noor Azira Tengku Zainudin ${ }^{3}$ \\ Nur Khalidah Dahlan ${ }^{4}$ \\ ${ }^{1}$ Faculty of Law, Universiti Kebangsaan Malaysia, Bangi, Selangor, Malaysia \\ ${ }^{2}$ Centre of Foundation Studies, Universiti Teknologi MARA, \\ Cawangan Selangor, Kampus Dengkil, Selangor, Malaysia. \\ ${ }^{3}$ Faculty of Law, Universiti Kebangsaan Malaysia, Bangi, Selangor, Malaysia \\ ${ }^{4}$ Faculty of Law, Universiti Kebangsaan Malaysia, Bangi, Selangor, Malaysia
}

${ }^{*}$ Corresponding Author

Doi: 10.2478/jesr-2019-0020

\begin{abstract}
National education in Malaysia is governed by the Education Act 1996 (EA 1996) (Act 550). At present, the subject of criminal law is not part of the Malaysian national secondary school curriculum. The lack of it has resulted in students being unable to get adequate and necessary exposure as well as understanding of the subject. It certainly does not coincide with the grim reality that crimes committed by school children are on the rise in Malaysia. This research is qualitative in nature, using a pure legal approach. This research adopted a content analysis method consisting of a detailed analysis of the Education Act 1996 (EA 1996) (Act 550), the Penal Code (Act 574) and the Child Act 2001 (CA 2001) (Act 611). In addition, this research also analyzed various journals and academic research in this area to discuss the importance of teaching criminal law as a subject in schools. The paper concludes that instead of introducing this subject at post-secondary education level, the subject should be considered to be taught earlier in secondary school. Early exposure to the criminal law subject would enable school children to be adequately informed on how the criminal justice system works and its relevant principles and values. This would in consequence create awareness and promote good values for students at a young age, namely the values of respect and adherence to the law which would help them to refrain from committing crimes.
\end{abstract}

Keywords: criminal law subject, secondary schools, Education Act 1996, Child Act 2001

\section{Introduction}

The Ministry of Education (MoE) is entrusted with providing Malaysian students with quality education (Grapragasem, Krishnan \& Mansor, 2014). National education in Malaysia is governed by the EA 1996. The EA 1996 basically provides for education and for matters connected therewith. In the EA 1996, it essentially sets out the responsibilities of the Government to provide education in Malaysia. In relation to national education, reference can be made to Part IV of the EA 1996. A reading of section 15 of the EA 1996 indicates that the national education system in Malaysia can be classified into five categories, namely pre-school education, primary education, secondary education, post-secondary education and higher education. For the purpose of this paper, focus will 
be given to secondary education because of its relevance to this paper in terms of crimes among school children. For primary education, pursuant to section 9 of the EA 1996, it provides that its duration is 6 years, but may be completed within 5 to 7 years. Generally, students of primary schools start schooling at age 7 and will complete their primary school education at 12 years old (commonly referred to as "standard 1" to "standard 6") (6 years). After completing primary education, then only the students can proceed with secondary education as spelt out in section 2 of the EA 1996. Secondary education means education including lower secondary and upper secondary education. Students of secondary schools generally begin at the age of 13 and will end when they are 17 (5 years) (commonly referred to as "form 1" to "form 5").

It is important to highlight that the preamble of the EA 1996 explains that "WHEREAS the purpose of education is to enable the Malaysian society to have a command of knowledge, skills and values necessary in a world that is highly competitive and globalised, arising from the impact of rapid development in science, technology and information." This shows that education in Malaysia should be holistic, encompassing a wide ranging of areas, namely knowledge, skills and values. The word 'values' can be defined as "the beliefs people have, especially about what is right and wrong and what is most important in life, that control their behaviour" (Values, n.d.). This shows that values are considered as one of the most important aspects that should be instilled in students. Due to this, the MoE should map its national curriculum with the purpose of education as spelt out in the preamble of the Act. The MoE has addressed this point via the Malaysia Education Blueprint 2013-2025 where the Blueprint aspires to create: "An education system that gives children shared values and experiences by embracing diversity." While it is undeniable that many positive values can be seen in a number of subjects taught in schools particularly Islamic education and moral education (Abdul Rahman, 2014), less emphasis is placed on the need to understand criminal principles and values, namely the significance of compliance with the law and the adverse effects of committing crime. To date, there is no specific subject on criminal law either in primary or secondary schools. Although the students are young in age, the trend shows that they have the capability and inclination to commit crimes. Crimes committed by school students range from minor misdemeanors to the most unimaginable heinous offences. In other words, crimes can be committed by a person irrespective of his age. There are a number of reasons why students are committing crimes; for example, bad influences by peers, poor supervision or lack of involvement by the parents towards child development, being raised by abusive parents or coming from a broken family (Azad, Hau, \& Karlsson, 2018; Lipsey \& Derzon, 1998). Examples of offences committed by school students are theft, snatch-theft, drug peddling, home breakings, rape, injury, robbery and murder. A study by the Malaysian Crime Prevention Foundation found that cases involving children were growing drastically. In 2012, there were 3,700 cases involving children. However, in 2013 , this number had significantly increased to 7,816 cases. The shift from 3,700 cases to 7,816 cases showed a huge increase of 112 percent. What is more alarming is that there has been an increase of cases involving students who were still in school. The number of students involved has increased from 1,042 cases in 2012 to 1,632 cases in 2013, an increase of 50 percent. This also involves serious crimes committed by children. In terms of serious crimes, there was an increase of 110 percent, showing an upward trend from 1,200 cases to 2,553 cases (Official Statement of Parliament, DN 22.4.2014, p. 80).

Providing holistic education is one of the main focuses of the MoE (Hazhari \& A. Hassan, 2009). This can be seen in the effort made by the MoE to formulate a new curriculum, which is expected to be launched by the end of 2020 or early 2021 (Samadi, 2018). Thus, it is hoped that the figures above are significant enough to trigger the MoE to review its National Education Policy (NPE) on the need to incorporate the criminal law subject into the national education curriculum. This is because the absence of the criminal law subject at the level of primary and secondary schools coincides with the reality that crimes committed by adolescents are on the rise in Malaysia.

\section{Methodology}

This research is qualitative in nature with a pure legal approach. This research adopted a content analysis method consisting of a detailed analysis of the EA 1966, the Penal Code and the CA 2001. 
In addition to that, this research also analyzed various journals and academic research in this area to discuss the importance of teaching criminal law in schools.

\section{Criminal Liability of a Child}

Looking at the age of students of primary and secondary schools, they are usually below eighteen years old and have not yet reached the age of majority as provided in section 2 of the Age of Majority Act 1971 (Act 21). Thus, students of primary and secondary schools in Malaysia are considered as a child under section 2 of the CA 2001. This definition is consistent with the interpretation set out in Article 1 of the Convention on the Rights of the Child (CRC). However, in relation to criminal proceedings, a child is defined as a person who has attained the age of criminal responsibility as prescribed in section 82 of the Penal Code. The section basically sets the minimum age of criminal responsibility at 10 years of age (Anita, 2010). The section says "Nothing is an offence which is done by a child under ten years of age." This indicates that Malaysian criminal law provides immunity for a child offender under the age of 10 . The children are given full exemption from their criminal responsibility since they are considered doli incapax, a Latin term which literally translates as incapable of doing wrong (Anita, Tengku Noor Azira, Ramalinggam, 2015). Thus, a child below 10 years old is presumed to be incapable of committing crime. The presumption cannot be rebutted (also known as the rule of "irrebuttable presumption") resulting in no offence being committed. Meanwhile, a child who is between 10 and 12 years does not enjoy complete immunity from committing crime. This is because the child is subjected to a different test laid down in section 83 of the Penal Code, which depends on whether the child has "attained sufficient maturity of understanding to judge of the nature and consequence of his conduct on that occasion." This section can serve as a defence for a child whose age falls within the said range. Thus, in view of section 105 of the Evidence Act 1950, should the child wish to plead this section as a defence against any offence, then the burden of proof lies on the child. It is important to note that the defence must not only be pleaded but also supported with relevant evidence (Crofts, 2002). Based on the case law, in determining whether the test has been met or not, the court may consider a few relevant factors, namely the type or nature of the crime and the behaviour of the child before and after the offence has been committed (T v DPP [1997] CRim.LR 127].

For a child who does not fall under the above criteria, the child is regarded as capable of committing crimes and therefore can be held criminally liable. However, being a child, certain protections are given to them in which the process of trial and punishment is subject to the CA 2001. Thus, children whose ages fall within the ambit of the CA 2001, if found guilty for offences committed, will be dealt by the CA 2001, namely section 91 . This means that although the child is found guilty under the offending section under the Penal Code, in terms of punishment, it will be subjected to the Order that may be issued by the magistrate as specified in section 91 of the CA 2001. For the purpose of clarity, the text of the said section is reproduced below:

If a Court for Children is satisfied that an offence has been proved the Court shall, in addition to any other powers exercisable by virtue of this Act, have power to-

(a) admonish and discharge the child;

(b) discharge the child upon his executing a bond to be of good behaviour and with such conditions as may be imposed by the Court;

(c) order the child to be placed in the care of a relative or other fit and proper person-

(i) for such period to be specified by the Court; and

(ii) with such conditions as may be imposed by the Court;

(d) order the child to pay a fine, compensation or costs;

(da) make a community service order;

(e) make a probation order under section 98;

(f) order the child to be sent to an approved school or a Henry Gurney School;

(g) [Del. Act A1511]

(h) impose on the child, if he is aged fourteen years and above and the offence is punishable with imprisonment and subject to subsection 96(2), any term of imprisonment which could be awarded by a Session Court. 
Hence, it may be argued that children above ten years old can be made criminally liable for offences committed. The statistics discussed above shows that crime among school children is on the rise. Although legal intervention can be taken against them under the provisions of the Penal Code read together with the CA 2001, it is argued that earlier exposure to the criminal law subject in national secondary school would provide the best platform for students to learn about the subject. It is proposed that this subject be taught in national secondary schools rather than primary schools because of the level of difficulty of this subject that may be burdensome to the students of early years in primary schools. Since this subject can be considered to be a heavy subject, teaching it to students in secondary school would therefore be more impactful since it is hoped and believed that the majority of the students at that stage would have reached the necessary level of maturity, thus enabling them to appreciate and comprehend the subject. Through this, it allows school children to be adequately informed with the contents relating to criminal law. This would create early awareness and promote good values for students at a young age, namely, respect and adherence to the law which would help them avoid committing crimes.

\section{The Importance of Introducing the Criminal Law Subject in Secondary School Curriculum in Malaysia}

Crime prevention is essential to prevent crime among students. Knowing that crimes among student are prevalent, prevention should start at an early age (Zainab Mahirah \& Nik Suryani, 2012). Crime prevention should include strategies and measures aimed at reducing the risk of crime among students. Research shows that there are many examples of preventive programs, including community-based programs in collaboration with enforcement agencies such as police, setting up crime preventive associations in school to promote adherence to law and also teaching criminal justice course in schools (Greenwood, 2008; Norehan, 2013; Cheurprakobkit \& Bartsch, 2000). Among these three instances, the introduction of the criminal law subject in schools would be seen as a better solution since the subject can be made compulsory as compared to the previous two in which the involvement may be merely voluntary and cannot possibly cater to all students. Moreover, considering the amount of time spent by students in school, school would be the best place to prevent crime among school children through education by having them learn and study criminal law.

The effects or consequences of crime prevention are what define it, not intentions. There are two ways in which consequences or effects can be viewed: first, from the number of criminal offences; and second, through the number of criminal offenders (Hirschi, 1969). Other authors have based their definition on the number of crimes or injuries prevented (Reiss and Roth, 1993: 59-61) or through the number of victims of crime (Farrell, 1995). Regardless of the measurement, what needs to be seen in a crime prevention programs is their effectiveness in preventing or reducing the crime rate. One of the key aspects of the crime prevention program is the introduction of the criminal law subject to secondary school students in Malaysia, in light of the discussion on crime prevention in this paper. School can be regarded as a place that has a direct relationship between family and community. In terms of the amount of time available to reduce the risk factors of crime, the school environment has more opportunities to achieve the objective of combating crime among school students (Denise C Gottfredson, 1990).

The Internet has been and is currently an essential component of human daily life with the fast growth of technology. The increase in Smartphone usage among students makes it easy for them to access the Internet. While the Internet is beneficial to students in terms of accessing information and enabling them to do research anywhere, it has more than its fair share of disadvantages without students realizing it. Lack of criminal law knowledge could lead students to believe they are not criminally responsible for what happens on cyberspace. The question that arises here is how far do students in school know about cyber-crimes and do they realize or understand that their actions can amount to a cyber-crime? Therefore, rather than using the Internet for good reasons, there are students who utilize them as a means to spread rumors, embarrassing stories and obscene images to humiliate their friends through various social media platforms such as Facebook, Instagram and Twitter without knowing the potential legal implications on them. It should be noted that ignorance 
of law cannot serve as a valid excuse for crimes committed. This is consistent with a Latin maxim of ignorantia legis neminem excusat or ignorantia of a non-central jurist which means that "Ignorance of the law is no excuse" (Yochum, 1999). It means that ignorance of law is not an excuse for violating the law. The issue of a person's knowledge on whether his actions have violated the law is irrelevant. According to the law, when a person is proven to have committed an act contrary to the law, he shall be responsible for his act. This may prompt an important question: what are the necessary actions or initiatives taken to expose and educate students about the laws of the country, in particular the criminal laws that could have a great impact on the students? Thus, introducing the criminal law subject is essential not only to explain the criminal law itself, but also to explain crime prevention and the negative consequences of committing crimes. Certainly, ignorance of law among students must be eliminated through criminal law subject in schools. Each and every secondary school student must know about criminal law so that they do not violate the law, especially by committing crimes that will have a major negative implication on their lives. In addition, the incorporation of the criminal law subject in the school syllabus will expose the students to the type of acts that can amount to criminal offences and the punishments provided by law for such offences.

As of now, criminal law has not been taught as a subject that is part of the secondary school curriculum anywhere in the world. However, some jurisdictions offer law-related subjects to the students. In the United States, the subjects most closely related to criminal law, namely Criminal Justice and the Law are introduced in some states, but the approach and purpose of the subject is more to give exposure to students about various career prospects in the field of criminal justice rather than for preventing crime among school students. Recently, states such as Texas, Florida, New York, Nebraska, and California have developed several courses of criminal justice and public safety to be taught in secondary school or high school. For instance, in the article titled "Teaching Criminal Justice and Law in High Schools," Marie Owens has explained that several states in the US like Texas, Florida, New York, New Jersey and Virginia have already introduced the subject of criminal justice and law in high school. Certain vital aspects of criminal justice such as forensic science, psychology and law are introduced to students. They are also trained to develop critical thinking skills through the subjects of law and criminal justice.

This development is based on the Law-Related Education Act of 1978 which calls for school students to be knowledgeable about the law, the criminal justice system as well as human rights and the people's constitution (Cheurprakobkit \& Tak Cheung Chan, 2011). The Law-Related Education Act of 1978 is based on a philosophy that it is important for the public to obtain information on laws that are a key element in the United States (Cheurprakobkit \& Tak Cheung Chan, 2011).

In addition, the curriculum can also serve as a prevention mechanism for crime and violence in schools (Bartsch \& Cheurprakobkit, 2002; Cheurprakobkit \& Bartsch, 2000; Kru \& Counts, 1998; Hughes, 2004; Pereira \& Rodriquez, 1997).

The importance of teaching criminal law has also been stated by Lawrence Sherman in a report prepared for the National Institute of Justice entitled "Preventing Crime: What Works, What Does not, What's Promising" (Sherman, et al., 1997). According to him, the teaching of law at school is something to be done in conjunction with similar programs such as anti-bullying campaigns. The community will benefit from students being disinclined to commit crime.

In sum, the introduction of the criminal law subject in schools, particularly secondary schools, is necessary and relevant. Literacy in criminal law will enable students to understand the crimes punishable by law. Students will be aware of the consequences and the punishment that follows if they commit crime. Consequently, this will prevent and deter the students from being involved in any crime-related activities.

\section{Conclusion}

Although legal action can be taken against children above ten years old under the existing legal framework, the crime rate among school children is still on the rise. The increased crime rate reflects the inadequacy of existing legal mechanisms to serve as deterrence to prevent school 
children from committing crimes. Mere reliance on the existing legal framework indicates that we have adopted a 'wait-and-see' approach, whereby we are just waiting for the children to commit an offence, and then punish them with the hope that they will not commit the same in the future. Instead of using the passive approach, it is humbly submitted that it is high time for the Government to take proactive measures through reforming the national education curriculum by inserting the criminal law subject in the national secondary school curricula. Indeed, school is one of the formal institutions that can assist in the prevention of crime. Earlier exposure to the criminal law subject would allow school children to be adequately informed on how the criminal justice system works and its relevant principles and values. This would create awareness and promote good values for students at a young age, namely respect and adherence to the law which would help them to avoid committing crimes.

\section{Acknowledgement}

This research is funded by Universiti Kebangsaan Malaysia (UKM) through research grant i.e. DCP-2017-009/5.

\section{References}

Abdul Rahman Md Aroff. (2014). Values education and the Malaysia education blueprint. Journal for Interdisciplinary Research in Education (JIRE), 4(1), 1-15.

Anita Abdul Rahim, Tengku Noor Azira Tengku Zainudin, Ramalinggam Rajamanickam. (2015) The involvement of school students in criminal activities and its position in the Malaysian Law. Mediterranean Journal of Social Sciences, 6(4), 403.

Anita Abdul Rahim. (2010). Lakuna Dalam Pemakaian Dalihan Ketidakmatangan Menurut Undang-undang Jenayah di Malaysia. Jurnal Undang-undang dan Masyarakat, 14, 197-222.

Azad, A., Hau, H. G., \& Karlsson, M. (2018). Adolescent Female Offenders' Subjective Experiences of How Peers Influence Norm-Breaking Behavior. Child and Adolescent Social Work Journal, 35(3), 257-270.

Cheurprakobkit, S., \& Bartsch, R. A. (2000). School crime and education: is there a need for criminology/criminal justice courses in the high school curriculum. Journal of Security Administration, 23(2), 1.

Crofts, T. (2002). The Criminal Responsibility of Children and Young Persons. England; Ashgate

Denise C Gottfredson. (1990). School Based Crime Prevention, National Criminal Justice System.

Grapragasem, S., Krishnan, A., \& Mansor, A. N. (2014). Current Trends in Malaysian Higher Education and the Effect on Education Policy and Practice: An Overview. International Journal of Higher Education, 3(1), 8593.

Greenwood, P. (2008). Prevention and Intervention Programs for Juvenile Offenders. The Future of Children $18(2), 185-210$.

Hazhari Ismail \& A. Hassan. (2009). Holistic education in Malaysia. European Journal of Social Sciences, 9(2), 231-236.

Lipsey, M. W. \& Derzon, J. H. (1998). Predictors of violent or serious delinquency in adolescence and early adulthood: A synthesis of longitudinal research. In R. Loeber \& D.P. Farrington (Eds.), Serious and violent juvenile offenders: Risk factors and successful interventions (pp.86-105). Thousand Oaks, CA: Sage Publishing Limited.

Norehan Saleh. (2013). Cegah jenayah bermula dari sekolah. Utusan Online. Retrieved from http://www.utusan.com.my/berita/wilayah/pahang/cegah-jenayah-bermula-dari-sekolah-1.211500.

Penyata Rasmi Parlimen, Dewan Negara, Parlimen Ketiga Belas, Penggal Pertama, Mesyuarat Pertama, Cawangan Penyata Rasmi Parlimen Malaysia, 2014 (DN 22.4.2014)

Samadi Ahmad. (2018, Novermber 13). New education curriculum to be implemented in 2021-Maszlee. News Straits Time, Retrieved from https://www.nst.com.my/news/nation/2018/11/430754/new-educationcurriculum-be-implemented-2021-maszlee.

Sherman, L. W., et al. (1997). Preventing crime: What works, what doesn't, what's promising: A report to the United States Congress. Washington, DC: US Department of Justice, Office of Justice Programs. (1997). Preventing Crime: What Works, What Doesn't, What's Promising. Report to the U.S. Congress. Washington, D.C.: U.S. Dept. of Justice.

Values. (n.d.). In Cambridge Dictionary. Retrieved from https://dictionary.cambridge.org/dictionary/english/value.

Yochum, M. D. (1998). The death of a maxim: ignorance of law is no excuse (killed by money, guns and a little sex). John's J. Legal Comment., 13, 635. 
Zainab Mahirah Ismail \& Nik Suryani Nik Abdul Rahman. (2012). School Violence and Juvenile Delinquency in Malaysia: A Comparative Analysis between Western Perspectives and Islamic Perspectives. ProcediaSocial and Behavioral Sciences, 69, 1512-1521. 